\title{
PENGELOLAAN PANTI ASUHAN SANTA MARIA: LAPORAN KEUANGAN USAHA DAN DESAIN RUANG KREATIF
}

\author{
Fransiska Soejono ${ }^{1}$, Suzzana Winda Artha Mutika², Latius Hermawan ${ }^{3}$, Theresia

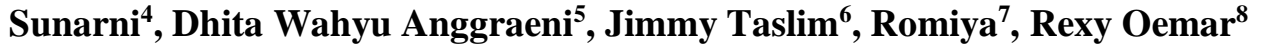 \\ Universitas Katolik Musi Charitas, Palembang \\ Email: fransiskasoejono@gmail.com / fransiska@ukmc.ac.id
}

\begin{abstract}
Saint Mary's Orphanage Pasang Surut is located in the Banyuasin Region of South Sumatra. The problem encountered today is the recording of financial statements that are simple using books and there are rooms that have not been used optimally. There is a need to redesign the room to fulfill the creativity of orphanage children. There are no human resources in the Panti who have the competence to create creative space designs. The solution to this problem is to conduct training activities on financial report making and creation of creative designs to optimize the use of one of the in-room spaces. The activity aims to improve the knowledge and skills of the institution manager and produce creative space design. The results of the activity are an increased understanding of financial reports and the use of Microsoft Office Excel to create business financial statements. The results of other activities are creative space design that is in line with the expectations of the institution manager.
\end{abstract}

Keyword : Orphanage, Financial Report, Creative Room

\begin{abstract}
Abstrak. Panti Asuhan St. Maria Pasang Surut terletak di Daerah Banyuasin Sumatera Selatan. Permasalahan yang ditemui saat ini adalah pencatatan laporan keuangan yang sederhana menggunakan buku dan ada ruangan yang belum digunakan secara optimal. Ada kebutuhan untuk mendesain ulang ruangan untuk pemenuhan kreativitas anak-anak panti. Belum ada sumber daya manusia di Panti yang memiliki kompetensi untuk membuat desain ruang kreatif. Solusi dari masalah tersebut adalah dilakukan kegiatan pelatihan mengenai pembuatan laporan keuangan dan pembuatan desain kreatif untuk mengoptimalkan penggunaan salah satu ruang dipanti. Kegiatan bertujuan untuk meningkatkan pengetahuan dan ketrampilan dari pengelola panti dan menghasilkan desain ruang kreatif. Hasil kegiatan adanya peningkatan pemahaman tentang laporan keuangan dan pemanfaatan Microsoft Office Excel untuk membuat laporan keuangan usaha. Hasil kegiatan lainnya adalah desain ruang kreatif yang sesuai dengan harapan pengelola panti.
\end{abstract}

Kata Kunci : Panti Asuhan, Laporan Keuangan, Ruang Kreatif

\section{PENDAHULUAN}

Panti Asuhan Santa Maria Pasang Surut mulai benar-benar berfungsi pada bulan Maret tahun 1986, dibawah pimpinan Romo Petrus Abdi Putra Raharja, SCJ. (http://www.scj.or.id/indonesia/info/PA_Pasan gSurut.htm). Dalam perjalanan Panti Asuhan memasuki tahun ke-33, Panti Asuhan Santa Maria mengalami perkembangan yang cukup baik. Bergabungnya pengelola panti dalam forum Panti Asuhan di tingkat regional maupun nasional menjadi daya dorong/pemicu peningkatan pengelolaan Panti Asuhan.

Letaknya berada di Desa Purwodadi kecamatan Muara Padang, kabupaten Banyuasin Sumatera Selatan. Saat ini Panti Asuhan di kelola oleh Rm. Antonius Effendi, SCJ. Menurut salah seorang alumni Panti Asuhan (Surono, 2017), profesionalisme dalam pembinaan anak Panti melahirkan generasi yang berguna bagi gereja dan masyarakat (http://majalah.hidupkatolik.com/2017/08/03/6 444/kasih-maria-menyertai-30-tahun-pantiasuhan-st-maria-pasang-surut-banyuasin, 3 Agustus 2017). Menurut Oktaviana dan Wibisono (2013), fasilitas panti asuhan dapat mengoptimalisasi proses tumbuh kembang anak. Hutasuhut (2017) menyatakan bahwa perancangan ulang (re-desain) yang melibatkan peran desain interior dari segi tata ruang, warna dan pencahayaan, material dan pembiayaan, serta fungsi fasilitas tersebut ditujukan untuk memenuhi kebutuhan anak dalam membentuk perkembangan anak secara fisik, mental dan sosial. Hasil survey Oktaviana dan Wibisono (2013), Hutasuhut (2017), dan Syahara (2017), ditemukan masih banyak panti asuhan yang belum mengoptimalisasi tumbuh kembang anak dari segi fasilitas seperti fasilitas ruang yang tidak sesuai dengan kebutuhan aktivitas anak, 
termasuk didalamnya menunjang kreativitas dan bakat anak. Fitri dkk. (2017) juga menemukan bahwa penyediaan fasilitas, ruangan yang tersedia tidak memenuhi standar pemerintah dan kebutuhan anak yang tinggal di panti asuhan. Berdasarkan hasil survey tim di Panti Asuhan Santa Maria Pasang Surut, masalah terkait optimalisasi ruang dan fasilitas juga ditemui di Panti Asuhan Santa Maria Pasang Surut. Namun Pengelola Panti Asuhan yaitu Romo Efendi sudah memiliki pemikiran dan rencana untuk mendesain ulang ruang dan gedung untuk memenuhi kebutuhan perkembangan anak. Hanya saja, keterbatasan SDM untuk desain ruang dan gedung di Panti membuat rencana belum segera terlaksana. Saat ini, Sumber Daya Manusia di UKMC sangat
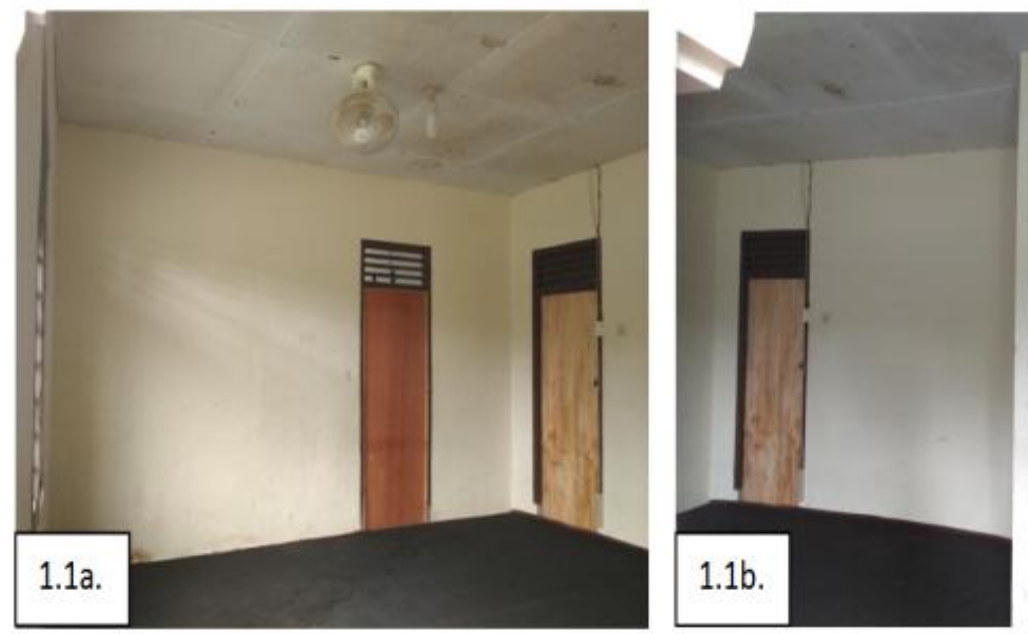

memungkinkan untuk membantu permasalahan ini.

Berdasarkan hasil wawancara dengan pengelola panti asuhan, diperoleh informasi bahwa terdapat satu ruang yang belum dimanfaatkan. Ruang tersebut sebelumnya digunakan untuk ruang belajar dan dalam ruangan terdapat lorong pendek menuju ke kamar mandi. Penggunaan ruang sempat diubah. Lorong pendek (akses) ke kamar mandi ditutup dan ruangan tersebut dijadikan ruang komputer. Namun karena sempit, akhirnya ruang komputer dipindahkan ke ruangan lain. Sehingga ruang tersebut kini menjadi kosong belum dimanfaatkan kembali. Ruang tersebut rencananya akan dijadikan ruang kreatif, tempat anak-anak belajar dan bermain bersama.

Gambar 1. Kondisi ruangan yang akan dijadikan ruang kreatif.

Gambar 1. menunjukkan ruangan yang belum difungsikan secara normal dan sudah lama tidak digunakan. Gambar diambil dari pintu masuk. Dalam ruangan terlihat pintu penghubung ke ruangan lain dan juga tampak lorong pendek di sudut-sudut ruangan.

Selain mengenai optimalisasi pemanfaatan ruang, kegiatan pengabdian ini juga fokus pada masalah pelaporan keuangan yang masih sederhana dan manual. Panti Asuhan memiliki usaha kecil yang dirintis tahun 2016 dengan pencatatan keuangan yang sederhana dan dilakukan secara manual. Sebelumnya pernah digunakan Ms. Excell dalam pencatatan keuangan, namun karena orang yang diberi tanggung jawab mencatat keuangan sudah tidak lagi tinggal di Panti dan belum sempat mengajarkan kepada orang yang melanjutkan tugas dan tanggung jawab mencatat laporan keuangan, maka pencatatan saat ini dilakukan secara manual. Pencatatan manual ini menggunakan buku tulis, yang rentan rusak dan hilang datanya. Sementara jaman sudah berkembang, sehingga kemajuan teknologi komputer yang ada dapat dimanfaatkan untuk mengatasi risiko rusak dan hilangnya data keuangan. Oleh karena itu, diperlukan ketrampilan komputer minimal seperti Ms. Excell agar pencatatan keuangan lebih rapi dan aman. Laporan Keuangan di Panti Asuhan saat ini masih dibuat secara manual (ditulis dalam buku). Gambar 2. menampilkan laporan keuangan yang dibuat Pengelola Panti Asuhan untuk selama tiga bulan ini yaitu Januari, Februari dan Maret tahun 2018. Shonhadji dkk. (2017) menyatakan UMKM lebih banyak berfokus pada kegiatan operasional sehingga pencatatan dan pelaporan seringkali terabaikan. Laporan keuangan sangat diperlukan ketika kita berhubungan dengan pihak kreditor. 


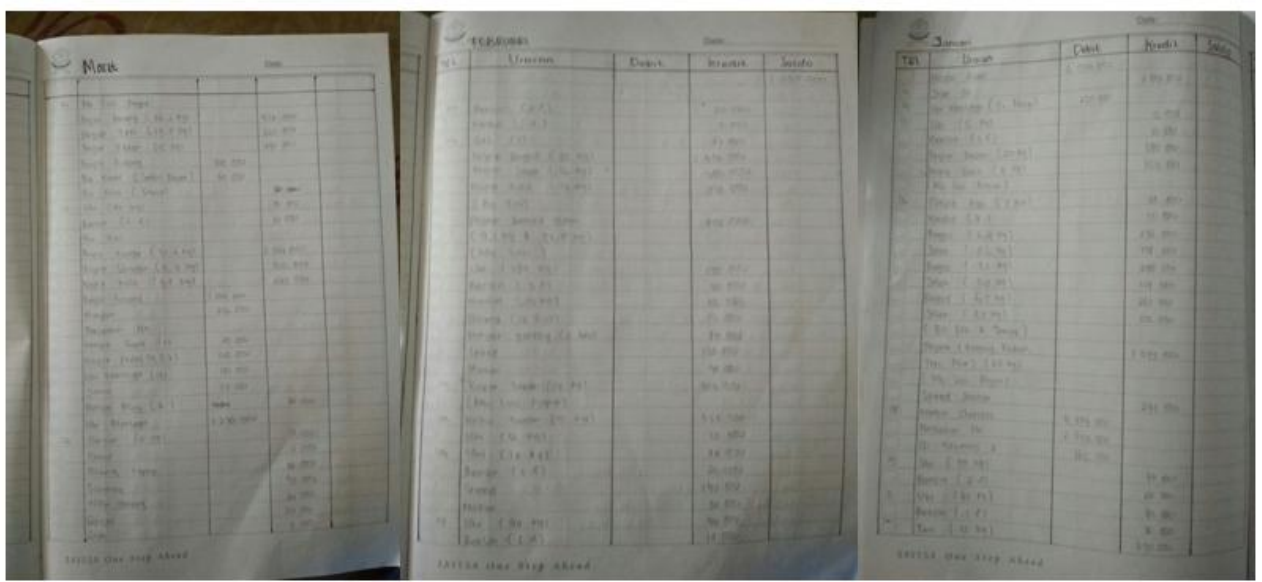

Gambar 2. Laporan Keuangan Panti Asuhan.

Menurut Pratiwi (2012), melalui penataan dan pembuatan laporan keuangan dengan baik dan benar, diharapkan kelak para pemilik usaha sederhana tidak akan kesulitan lagi ketika mengajukan kredit kepada pihak kreditur. Untuk itu, penyusunan laporan keuangan dilakukan secara berkesinambungan. Dalam hal ini, lembar kerja elektronik Microsoft Excel sangat membantu dalam penyusunan laporan keuangan. Shonhadji dkk. (2017) juga menegaskan bahwa penyusunan laporan keuangan berbasis Microsoft Excel terbukti sangat membantu mitra untuk menyelesaikan kendala yang ada masih terkait dengan pihak eksternal. Oleh karenanya, tim membantu pengelola untuk memahami penyusunan laporan keuangan dengan memanfaatkan Microsoft Excel.

\section{METODE}

Kegiatan yang dilakukan ada dua. Kegiatan pertama berupa pembuatan desain ruang kreatif dan ruang makan dilakukan selama kurang lebih tiga bulan. Kegiatan ini dilakukan melalui tahapan survey lokasi (ruang), desain ruang kreatif, diskusi desain dan sosialisasi desain. Kegiatan kedua berupa pengenalan bentuk-bentuk laporan keuangan dan pelatihan pembuatan laporan keuangan dengan menggunakan Ms. Excel. Kegiatan ini diselenggarakan di ruang kerja pengelola panti. Kegiatan ini menggunakan alat bantu berupa laptop/notebook. Kegiatan ini melalui tahapan pembuatan materi yang dibagikan ke peserta pelatihan dalam bentuk Ms. Excel. Kegiatan pelatihan dilakukan pada hari Sabtu, 21 April 2018.

\section{HASIL DAN PEMBAHASAN}

Pada awalnya pengelola panti membutuhkan desain untuk ruang dan gedung kreatif. Namun pada komunikasi awal pembuatan desain, pengelola menyatakan bahwa gedung (pendopo) kreatif sudah di desain oleh pihak lain. Pada akhirnya, pengelola mengubah permintaan desain dari gedung kreatif menjadi desain ruang makan. Proses pembuatan desain ruang kreatif dan ruang makan membutuhkan waktu kurang lebih 3 bulan (pertengahan Januari - pertengahan April) dan dilaksanakan dalam waktu yang bersamaan. Dalam proses pengerjaan terdapat sedikit hambatan yaitu dalam hal komunikasi. Hal ini terjadi karena komunikasi dilakukan jarak jauh menggunakan fasilitas whatsapp dan telepon. Masukan atas desain yang sudah dibuat tidak hanya dari pengelola, tetapi juga melibatkan pihak lain.

Sosialisasi desain ruang kreatif dan ruang makan dihadiri oleh pengelola. Ruangan yang digunakan untuk sosialisasi adalah ruang makan Panti Asuhan. Untuk mengetahui tanggapan pengelola atas desain yang sudah dibuat, tim mempersiapkan umpan balik dari pengelola menggunakan kuisioner yang terdiri dari 6 pernyataan tertutup dan 1 pertanyaan terbuka. Kuisioner dibagikan kepada pengelola dengan hasil/tanggapan sebagai berikut: Pengelola menyatakan setuju untuk pernyataan mengenai ruang kreatif sudah sesuai dengan harapan. Namun demikian masih diperlukan perbaikan dalam desain ruang kreatif. Pengelola juga sangat setuju untuk menggunakan desain ruang kreatif. Desain tersebut akan direalisasikan menjadi ruang kreatif yang diharapkan menjadi salah satu sarana yang mendukung pertumbuhan karakter anak panti. 


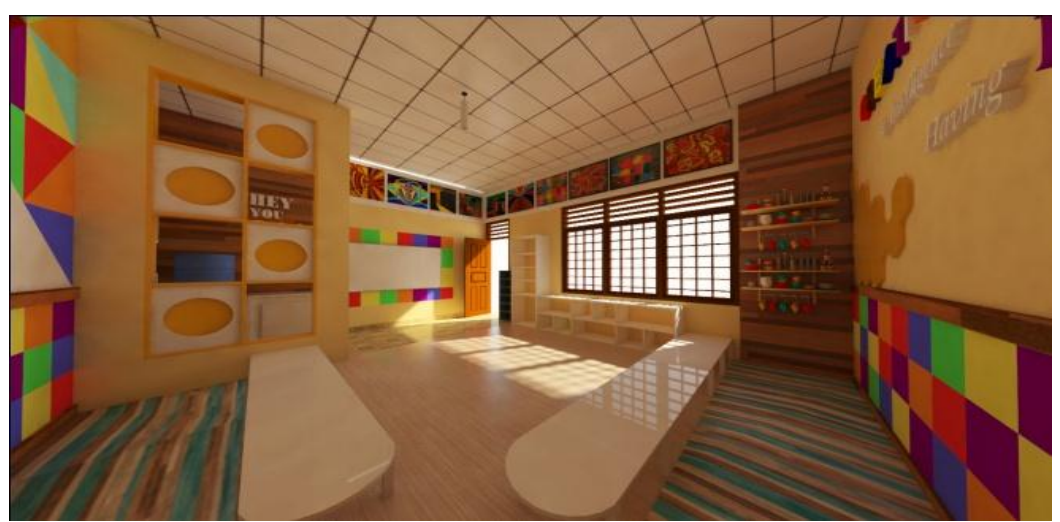

Gambar 3. Desain Ruang Kreatif.

Komentar Pengelola sebagai berikut: "Desain sudah bagus tinggal penambahan beberapa. Mohon dukungan terus agar desain terealisasi. Pada dasarnya, terdapat beberapa prinsip di dalam keuangan usaha terdiri dari: pertama, Pisahkan Keuangan Pribadi dan Usaha. Hal ini dilakukan agar keuntungan usaha dapat digunakan untuk diputar kembali menjadi modal usaha. Selain itu keuntungan usaha dapat digunakan untuk meningkatkan produktivitas usaha, dan dalam jangka panjang dapat terjaga kelangsungan usaha. Kedua, Tentukan Persentase Keuntungan untuk gaji bulanan misalnya 10-15\% dari keuntungan. Menurut Lim Rusyamsi seorang founder komunitas Tangan Diatas (TDA) (2012), idealnya $30 \%-50 \%$ dari laba kotor digunakan untuk gaji. Sedangkan laba bersih dapat digunakan untuk $20 \%$ untuk investasi dan dana cadangan, $10 \%$ untuk investasi usaha (SDM, Sistem, Infrastruktur, dll), 60\% untuk modal berputar (persediaan dan penjualan), $10 \%$ untuk keperluan pribadi (penghargaan diri), dan 10\% untuk dana sosial (CSR). Ketiga, Buat laporan keuangan atau pembukuan. Merina (2018) menyatakan bahwa Pembukuan sederhana sangat penting bagi bisnis UKM. Laporan keuangan dibuat untuk mengetahui cash flow usaha, mengontrol sekaligus menilai kinerja keuangan usaha, menjadi dasar pengambilan keputusan keuangan seperti keputusan pinjaman dan alokasi dana, dan untuk menghitung kewajiban pajak.

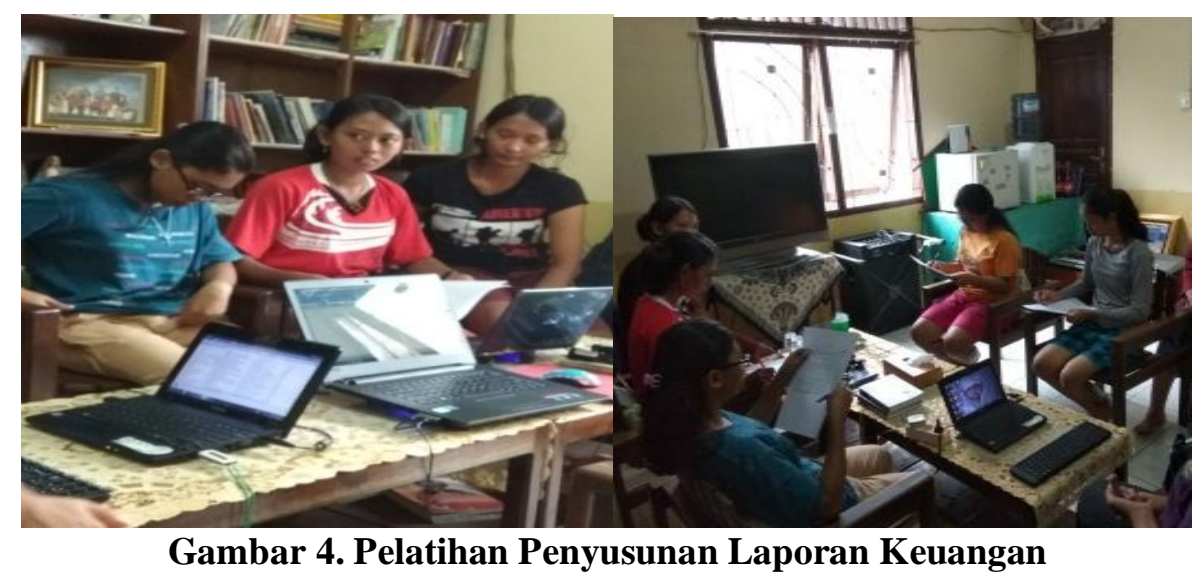

Menurut Rahmadhani (2018), ada tujuh pembukuan keuangan yaitu (1) Buku Arus Kas, (2) Buku Persediaan Barang, (3) Buku Pembelian, (4) Buku Penjualan, (5) Buku Biaya, (6) Buku Hutang, dan (7) Buku Piutang. Keempat, gunakan software untuk membantu proses pencatatan dan penyimpanan laporan keuangan.

Pelatihan pembuatan laporan keuangan menggunakan Ms. Excell (gambar 4.) menggunakan ruang kerja pengelola (romo
Efendi). Peserta Pelatihan pengelolaan website sebanyak 5 orang, 4 orang diantaranya mengikuti pelatihan dengan menggunakan fasilitas laptop/notebook (satu berdua), sedangkan satu orang lainnya hanya mendengarkan tanpa praktek. Lima peserta tersebut berjenis kelamin perempuan. Dua diantaranya adalah anak panti yang sudah senior dan sedang menjalani masa pengabdian setelah disekolahkan, yang satu lulusan SMk dan yang lain lulusan S1. Sedangkan tiga 
peserta lainnya adalah anak panti yunior masih menempuh pendidikan SMA. Untuk mengidentifikasi keberhasilan pelatihan, maka dilakukan pre dan post test menggunakan kuisioner dengan bentuk pertanyaan tertutup.
Kuisioner yang terkumpul dan diisi lengkap berjumlah 4 kuisioner (1 orang peserta yang tidak praktek namun hanya mendengar dan tidak ikut dalam pengisian kuisioner).

Tabel 1. Hasil rekapitulasi jawaban benar pre dan post test pelatihan penyusunan laporan keuangan

\begin{tabular}{lccc}
\hline \multicolumn{1}{c}{ Peserta } & Pre & Post & Hasil \\
\hline 1 & $92 \%$ & $100 \%$ & Meningkat \\
2 & $75 \%$ & $100 \%$ & Meningkat \\
3 & $75 \%$ & $100 \%$ & Meningkat \\
4 & $75 \%$ & $100 \%$ & Meningkat \\
Mean & $79,25 \%$ & $100 \%$ & Meningkat \\
\hline
\end{tabular}

Sumber: data primer yang diolah

Tabel 1. menunjukkan ada peningkatan pengetahuan (diukur dari banyaknya jumlah pertanyaan yang dijawab dengan benar) baik secara individu maupun secara rata-rata. Jawaban benar rata-rata sebelum pelatihan sebesar 79,25\%, seangkan sesudah pelatihan rata-rata sebesar $100 \%$. Dengan demikian, pelatihan dapat dikatakan berhasil karena peserta dianggap sudah memahami dan mampu menggunakan Microsoft Excell untuk membuat laporan keuangan sederhana. Kendati peserta yang dilatih berjumlah 4 orang, namun untuk penanggung jawab administrasi keuangan di Usaha SanMa Panti Asuhan ini hanya dilakukan oleh satu orang anak panti yang sudah lulus SMK. Tanggapan peserta atas pelatihan yang telah diadakan yaitu peserta menganggap pelatihan tersebut bermanfaat karena materi yang diberikan sesuai dengan kebutuhan saat ini. Pemberian materi jelas menurut peserta, selain itu peserta juga beranggapan bahwa dalam prakteknya lebih mudah dan aman menyusun laporan keuangan dalam bentuk Ms. Excel. Selanjutnya, penyusunan laporan keuangan dengan menggunakan Ms. Excel akan diterapkan untuk pencatatan laporan keuangan dipanti asuhan. Berdasarkan tanggapan/komentar terbuka dari peserta, tim menyadari bahwa masih diperlukan pendampingan lebih intens dan lebih efektif lagi dalam pembuatan laporan keuangan khususnya laporan keuangan periodik seperti semester atau tahunan. Pelatihan dilakukan untuk meningkatkan pengetahuan mengenai beberapa buku laporan keuangan dan pelaporan Neraca serta Laba Rugi, sedangkan secara praktek peserta hanya berkesempatan mencatatkan kembali laporan keuangan yang sudah dicatat secara manual ke dalam Ms.
Excell dan kemudian dilatihkan cara perhitungan tambah kurang bagi dan kali dengan menggunakan Ms. Excell. Orang yang dipercaya melakukan pencatatan keuangan dipanti asuhan selama ini sudah berganti-ganti, dan yang terakhir baru dua bulan ini ditempatkan di administrasi pelaporan keuangan (bendahara). Pencatatan keuangan yang sebelumnya pernah dilakukan dengan Ms. Excell hanya tidak diketahui keberadaan filenya karena admin sebelumnya sudah tidak tinggal di Panti lagi.

\section{SIMPULAN}

Berdasarkan hasil kegiatan dan umpan balik yang telah dihimpun dapat ditarik kesimpulan sebagai berikut: Pengelola Panti Asuhan terbantu dengan adanya desain ruang kreatif sehingga tahap berikutnya yang akan dilakukan pengelola adalah merealisasikan pembangunan ruang kreatif sesuai desain. Kerjasama dalam mewujudkan pembangunan ruang kreatif yang sesuai dengan desain masih akan terus berjalan. Diharapkan komunikasi antara tim dan pengelola dalam berjalan dengan baik. Diharapkan tim terutama koordinator pembuatan desain tetap melakukan pendampingan tim dalam penyempurnaan desain dan realisasi pembangunannya.Hal ini merupakan salah satu upaya untuk membentuk karakter anak-anak di Panti Asuhan Santa Maria. Pemahaman administrasi keuangan (bendahara) Panti Asuhan Santa Maria mengenai pembuatan laporan keuangan dan penggunaan Ms. Excell mengalami peningkatan. Panti Asuhan belum memiliki ijin usaha maupun ijin edar produk. Selanjutnya, panti asuhan masih membutuhkan pendampingan untuk legalitas usaha seperti ijin 
usaha dan ijin edar produk. Hal lain yang ditemukan adalah kondisi ruang belajar anak laki-laki di panti asuhan belum kondusif karena pencahayaan dan sirkulasi udara tidak memadai. Oleh karena itu, diperlukan disain ulang agar suasana belajar lebih nyaman. Pengelola juga memiliki rencana pembuatan taman di halaman panti asuhan namun masih membutuhkan desain taman terlebih dahulu. Oleh karenanya, diperlukan desain taman (termasuk di dalamnya terdapat gua Maria) yang dilengkapi dengan Rencana dan Anggaran Belanja (RAB).

\section{DAFTAR PUSTAKA}

Fitri, Sariani; Tri Haryotedjo, Rizka Rachmawati. 2017. Perancangan Interior Panti Asuhan Muhammadiyah Sumur Bandung. E-proceeding of Art \& Design. Vol. 4, No. 3 Desember 2017, page 12851294.

https://openlibrary.telkomuniversity.ac.id /pustaka/files/137173/jurnal_eproc/peran cangan-interior-panti-asuhanmuhammadiyah-sumurbandung.pdf $+\& \mathrm{~cd}=1 \& \mathrm{hl}=\mathrm{id} \& \mathrm{ct}=\mathrm{clnk} \& \mathrm{gl}$ $=$ id. ISSN: 2355-9349. Diakses tanggal 19 Maret 2018.

Hutasuhut, Ruspa Dewi Ankarani. 2017. Perancangan Ulang Interior Panti Asuhan Puteri William Booth. E-proceeding of Art \& Design. Vol. 4, No. 3 Desember 2017, page 1395- 1401 . https://openlibrary.telkomuniversity.ac.id /pustaka/files/137370/jurnal_eproc/peran cangan-ulang-interior-panti-asuhanputeri-william-booth-di-

bandung.pdf $+\& \mathrm{~cd}=1 \& \mathrm{hl}=\mathrm{id} \& \mathrm{ct}=\mathrm{clnk} \& \mathrm{gl}$ $=$ id. ISSN: 2355-9349. Diakses tanggal 19 Maret 2018.

Kongregasi SCJ. 2017. Panti Asuhan St. Maria "Pasang Surut". http://www.scj.or.id/indonesia/info/PA_P asangSurut.htm. diakses tanggal 6 Maret 2017.

Lim Rusyamsi, MM. 2012. Punya Usaha Untung, Tapi Bingung Bagi-bagi Laba. https://finance.detik.com/klinik-ukm/d2008377/punya-usaha-untung-tapibingung-bagi-bagi-laba. Diakses tanggal 18 April 2018.

M. Fransiska FSGM. 2015. Panti Asuhan St. Maria Banyuasin: Kasih Maria di Pasang Surut.

http://m.hidupkatolik.com/index.php/201 5/10/23/panti-asuhan-st-maria- banyuasin-kasih-maria-di-pasang-surut. diakses tanggal 6 Maret 2017.

Nely Merina. 2018. Tips Membuat Pembukuan Sederhana Untuk Bisnis. http://goukm.id/tips-membuatpembukuan-sederhana/. Diakses tanggal 18 April 2018

Oktaviana, Citra Lestari; dan Andriyanto Wibisono. 2013. Optimalisasi Tumbuh Kembang Anak Pada Pelayanan Panti Asuhan dengan Studi Kasus Ruang Interior. Jurnal Tingkat Sarjana Bidang Senirupa dan Desain, Vol.2, No1. http://jurnal-

s1.fsrd.itb.ac.id/index.php/interior/article/ view/295. Diakses tanggal 19 Maret 2018.

Pratiwi, Ririh Dian. 2012. Menyusun Laporan Keuangan Sederhana dengan Microsoft Excell. Media Informasi dan Teknologi Informasi. Vol. 19, No. 1. Hal. 64-70. file:///C:/Users/LPPM/Downloads/8962415-1-PB.pdf. diakses tanggal 21 Maret 2018.

Shonhadji, Nanang; Laely Aghe A.; dan Djuwito. 2017. Penerapan Penyusunan Laporan Keuangan pada UKM Berdasarkan SAK EMKM. Seminar Nasional HAsil Pengabdian kepada Masyarakat (SENIAS) 2017-Universitas Islam Madura. Hal. 130-136. http://webcache.googleusercontent.com/s earch?q=cache:Nih6ZqiSxnQJ:senias.ui m.ac.id/index.php/senias_2017/article/do wnload $/ 32 / 33+\& c d=3 \&$ hl $=$ jv\&ct $=$ clnk \& gl=id. Diakses tanggal 21 Maret 2018.

Suci Rahmadhani. 2018. Panduan Membuat Laporan Keuangan Sederhana Untuk UKM http://goukm.id/panduanmembuat-laporan-keuangan-untukusaha-mikro-dan-kecil-menengah-ukm/. Diakses tanggal 18 April 2018.

Syahara, Rizka. 2017. Perancangan Interior Panti Sosial Asuhan Anak Sartika di Bandung. E-proceeding of Art \& Design. Vol. 4, No. 3 Desember 2017, page 1270 1279. https://openlibrary.telkomuniversity.ac.id /pustaka/files/137197/jurnal_eproc/peran cangan-interior-panti-sosial-asuhan-anaksartika-di-

bandung.pdf $+\& c d=1 \& h l=i d \& c t=c \operatorname{lnk} \& g l$ =id. ISSN: 2355-9349. Diakses tanggal 19 Maret 2018. 